\title{
HSPA5 wt Allele
}

National Cancer Institute

\section{Source}

National Cancer Institute. HSPA5 wt Allele. NCI Thesaurus. Code C49546.

Human HSPA5 wild-type allele is located within $9 q 34$ and is approximately $6 \mathrm{~kb}$ in length.

This allele, which encodes $78 \mathrm{kDa}$ glucose-regulated protein, plays a role in protein

transport through the cell. HSPA5 allelic variants have been implicated in gastric tumor development. 